\title{
Towards an integrative approach to evaluate the environmental ecosystem services provided by urban forest
}

\author{
Samson Roeland ${ }^{1} \cdot$ Marco Moretti $^{2} \cdot$ Jorge Humberto Amorim $^{3} \cdot$ Cristina Branquinho $^{4}$. \\ Silvano Fares $^{5} \cdot$ Federico Morelli $^{6}$ • Ülo Niinemets ${ }^{7}$ - Elena Paoletti ${ }^{8}$. \\ Pedro Pinho $^{4,9}$ - Gregorio Sgrigna ${ }^{10}$ - Vladimir Stojanovski ${ }^{11}$ - Abhishek Tiwary ${ }^{12}$. \\ Pierre Sicard $^{13} \cdot$ Carlo Calfapietra $^{10,14}$
}

Received: 3 November 2018/Accepted: 15 January 2019/Published online: 22 March 2019

(C) The Author(s) 2019

\begin{abstract}
As a Nature-Based Solution, urban forests deliver a number of environmental ecosystem services (EESs). To quantify these EESs, well-defined, reliable, quantifiable and stable indicators are needed. With literature analysis and expert knowledge gathered within COST Action FP1204 GreenInUrbs, we proposed a classification of urban forest EESs into three categories: (A) regulation of air, water, soil and climate; (B) provisioning of habitat quality; and $(\mathrm{C})$ provisioning of other goods and services. Each category is divided into EES types: (a) amelioration of air quality; restoration of soil and water; amelioration of the microclimate; removal of $\mathrm{CO}_{2}$ from the air; (b) provision
\end{abstract}

Project funding: The work was financially supported by COST Action FP1204 GreenInUrbs, PRIN project EUFORICC, and Ministry of Education and Science of the Russian Federation (the Agreement No. 02.A03.21.0008).

The online version is available at http://www.springerlink.com

Corresponding editor: Yu Lei.

Elena Paoletti

elena.paoletti@cnr.it

1 Department of Bioscience Engineering, Research Group Environmental Ecology and Applied Microbiology, Laboratory of Environmental and Urban Ecology, University of Antwerp, Antwerp, Belgium

2 Swiss Federal Research Institute WSL, Biodiversity and Conservation Biology, Zürcherstrasse 111, 8903 Birmensdorf, Switzerland

3 Swedish Meteorological and Hydrological Institute (SMHI), SE-60176 Norrköping, Sweden

4 Faculdade de Ciências, cE3c-Centre for Ecology, Evolution and Environmental Changes, Universidade de Lisboa, Campo Grande, Lisbon 1749-016, Portugal of habitat for biodiversity; support for resilient urban ecosystems; provision of genetic diversity; and (c) provision of energy and nutrients; provision of grey infrastructure resilience. Each EES type provides one or more benefits. For each of these 12 benefits, we propose a set of indicators to be used when analyzing the impacts on the identified EESs. Around half of the 36 indicators are relevant to more than one single benefit, which highlights complex interrelationships. The indicators of wider applicability are tree and stand characteristics, followed by leaf physical traits and tree species composition. This knowledge is needed for the optimization of the EESs delivered by urban forests, now and in the future.

Keywords Urban forests · Environmental ecosystem services · Indicators

5 Council for Agricultural Research and Economics (CREA), Research Center for Forestry and Wood, Arezzo, Italy

6 Department of Applied Geoinformatics and Spatial Planning, Faculty of Environmental Sciences, Czech University of Life Sciences Prague, Kamýcká 129, 16500 Prague 6, Czech Republic

7 Institute of Agricultural and Environmental Sciences, Estonian University of Life Sciences, Kreutzwaldi 1, Tartu 51014, Estonia

8 Institute of Research on Terrestrial Ecosystems (IRET), CNR, Section of Florence, Via Madonna del Piano 10, Sesto Fiorentino, Italy

9 Centre for Natural Resources and the Environment, Instituto Superior Técnico, University of Lisbon, Lisbon 1749-016, Portugal 


\section{Introduction}

Urban areas are projected to accommodate $68 \%$ of the world's population by 2050 (United Nations 2018). Urban forests (including individual trees and shrubs, parks and forests) play a crucial role in improving the environmental quality of cities and urban dwellers (Roy et al. 2012; Shwartz et al. 2014). Conventional urban greening management primarily aims at enhancing amenity values (Pandit et al. 2013) and maintaining biodiversity (Llausàs and Roe 2012), but growing interest has been focusing on carbon (C) management perspectives (Grimm et al. 2008) and other environmental ecosystem services (EESs). Ecosystem services (ES) are defined as benefits that humans obtain from ecosystem functions (De Groot et al. 2002), or as direct and indirect contributions from ecosystems to human well-being (TEEB 2010). Many ES types have been identified and grouped into three (provisioning, regulating, and cultural services, Maes et al. 2016) or four categories (the former three, plus supporting services; TEEB 2010). A meta-analysis on urban ESs concluded that most studies were undertaken in Europe, North America and China, and that almost 50, 20, 11 and 15\% of the studies were about regulating, supporting, provisioning and cultural ESs, respectively (Haase et al. 2014). As compared to other ecosystems like wetlands or natural forests, the attention given to urban ESs is still insufficient (Gómez-Baggethun and Barton 2013), especially when the focus is on the urban forest alone (24\% of studies in the meta-analysis by Haase et al. 2014). In the analysis carried out in this paper we established that EESs include all ESs sensu stricto, except the cultural services (Fig. 1).

Because EESs are biodiversity-based, species composition and community structure occurring in urban forests are crucial for the delivery of any EES in cities (Cardinale et al. 2012). Air- and climate-related EESs comprise air purification, climate regulation and $\mathrm{C}$ sequestration (McDonald et al. 2007; Armson et al. 2012; Lafortezza and Chen 2016). Other goods and services comprise the delivery of energy, food, non-timber forest products

10 Institute of Research on Terrestrial Ecosystems (IRET), CNR, Headquarters, Via Marconi 2, Porano, Italy

11 Forest Faculty in Skopje, University SS Cyril and Methodius, 1000 Skopje, Macedonia

12 Faculty of Engineering and the Environment, University of Southampton, Highfield, Southampton SO17 1BJ, UK

13 ARGANS, 260 Route du Pin Montard, 06904 Sophia Antipolis, France

14 Department of Landscape Design and Sustainable Ecosystems, Agrarian-technological Institute, RUDN University, Miklukho-Maklaya Str., 6, Moscow, Russia 117198

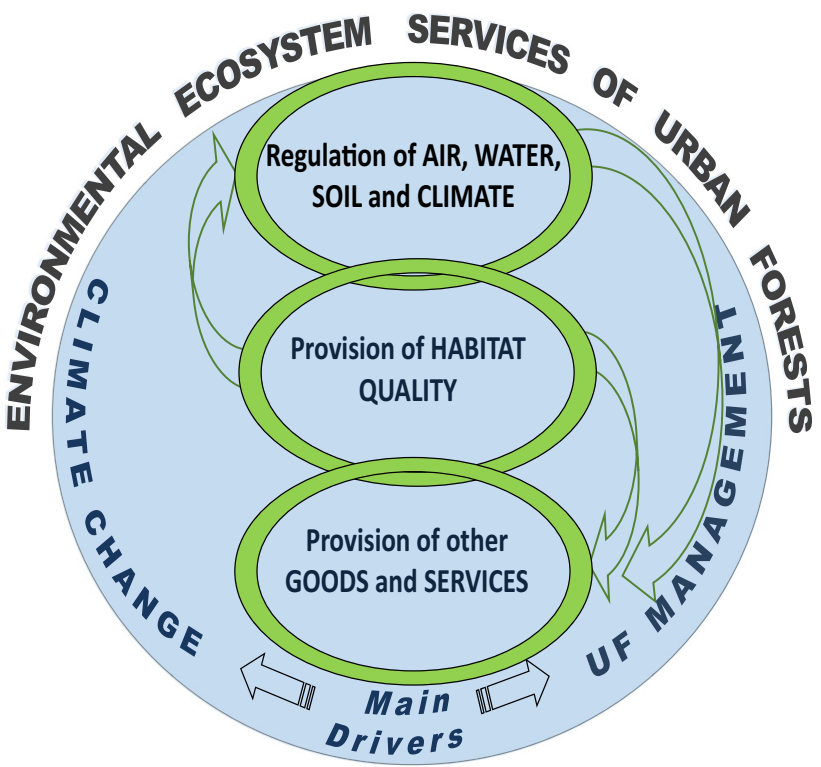

Fig. 1 Type, relationships and main drivers of the environmental ecosystem services (EESs) of urban forests (UF). We classify UF EESs into three categories: (1) regulation of air, water, soil and climate; (2) provisioning of habitat quality; and (3) provisioning of other goods and services, with habitat quality as central to the other two. Two main drivers (UF management and climate change) affect all the three EESs

(NTFPs), fresh and clean water, regulation of water runoff and erosion (Guo et al. 2000; Roy et al. 2012). These EESs act at the local level, i.e. at street or neighborhood scale, but may also exert an impact at the regional level, for example, in relation to climate- or water-regulating effects (Guo et al. 2000). Several urban forest EESs are coupled to each other. As an example, water availability can influence the cooling effect of urban forests, but can also affect the interaction of trees with air pollutants. Air pollution in urbanized areas can result in polluted soils (Davidson et al. 2006), surface waters (Le Pape et al. 2012) and groundwater (Gallo et al. 2012). Moreover, the different environmental conditions often observed within the urban environment as compared to its surroundings can affect the physiology of plants (Sicard et al. 2016) and consequently their capacity to provide EESs (Calfapietra et al. 2015). Science-based evidence on urban forest EESs is needed to identify and assess trade-offs, disservices (environmental, social and financial) and complex interactions among different EESs. For instance, certain tree species (e.g. poplars) might take up great amounts of ozone, which is beneficial in terms of air quality, but the same species might be a strong emitter of biogenic volatile organic compounds (BVOCs) and thus contribute to the formation of ozone itself (Calfapietra et al. 2013).

To quantify the urban forest EESs and untangle the complex interrelationships among them in a changing climate and under different socio-cultural conditions, EES 
indicators and their benchmark definitions should be identified. The EES indicators should be well defined, measurable, reliable and stable parameters that are directly or indirectly related with one or more ecosystem processes and underlying services. The identification and monitoring of indicators help to link decision making in urban planning and management with relevant scientific knowledge (Maes et al. 2016). Such is the case for biodiversity, where accounting for the needs of multiple biological groups is a challenge that can be addressed with the proper indicators (Pinho et al. 2016).

There is an urgent need to understand the complex relationships highlighted above, in particular considering the ongoing climatic and socio-economical changes that affect worldwide urbanized areas in an unprecedented way. Therefore, the aim of this paper is to provide an improved classification of urban forest EESs, discuss their benefits, specificity and relevance in the context of other EESs, and define a set of suitable indicators. This work is an outcome of the activities of the COST Action FP1204 'Green Infrastructure approach: linking environmental with social aspects in studying and managing urban forests' (GreenInUrbs).

\section{The environmental ecosystem services of urban forests}

\section{Classification of urban forest EESs}

We classified urban forest EESs into three main categories: regulation of air, water, soil and climate; provisioning of habitat quality; and provisioning of other goods and services. As shown by the green arrows in Fig. 1, habitat quality, in the broader sense of its definition, as the quality of the above and belowground space where urban trees live, is central for the provisioning of all the other EESs, while air, water, soil and climate EESs also affect the delivery of other goods and services (Chen et al. 2016; Giannico et al. 2016; Mariani et al. 2016; Pesola et al. 2017). A high habitat quality of the living space of urban trees will positively affect their growth, survival and reproduction, enhancing their potential provision of multiple functions and services. The main benefits and interlinkages are summarized in Fig. 2 by different colours. Fifty-three percent of the 36 indicators suggested herein are relevant to more than one single benefit, which highlights the complex interrelationships among different urban forest EESs. The indicators of wider applicability are tree and stand characteristics (e.g., density and continuity of the plant cover, tree age, architecture, diameter at breast height (DBH), leaf area index (LAI), canopy height, tree height), followed by leaf physical traits (shape, persistence, orientation, wettability, hairiness, roughness, toughness, albedo) and tree species composition (species identity and relative abundance). The relative importance of EESs, i.e. either the impact on the environment and the general perception by the population, differs along a rural-urban transect (Fig. 3). Amelioration of air quality and microclimate, as well as building preservation, are of utmost importance in cities given the density of population and built infrastructures, while $\mathrm{CO}_{2}$ sequestration, provision of energy, nutrients and resources, and restoration of soil and water are quantitatively more important for forests in rural areas. Habitat quality for biodiversity is extremely important in both urban and rural forests.

\section{Regulation of air, water, soil and climate}

By interacting with the atmosphere, urban forests provide valuable EESs to society. These services can be classified into three major types: (1) amelioration of air quality; (2) restoration of water and soil; (3) amelioration of the microclimate and removal of the greenhouse gas (GHG) $\mathrm{CO}_{2}$ from the atmosphere (Fig. 2). These EESs provide a number of benefits that are summarized as: (1) reduction of air pollution; (2) soil/water retention; (3) amelioration of thermal comfort; and (4) carbon sequestration (the numbers refer to the indicators in Fig. 2). For each benefit, a variety of indicators are suggested and discussed below. The indicators can be either characteristics of individual trees and tree canopies (written in light green in Fig. 2) or characteristics of the environment where the trees are located (in black in Fig. 2).

\section{Amelioration of air quality}

Urban air pollution is a major threat to citizens' health (Pascal et al. 2013). A plethora of primary pollutants, e.g. nitrogen oxides $\left(\mathrm{NO}_{\mathrm{x}}\right)$, sulphur dioxide $\left(\mathrm{SO}_{2}\right)$ and particulate matter (PM), are directly emitted by combustion in industrial processes and road and non-road transport (EEA 2015). Secondary pollutants, e.g. ozone $\left(\mathrm{O}_{3}\right)$ and secondary organic aerosols (SOA), are formed by reactions of precursors such as $\mathrm{NO}_{\mathrm{x}}$ and VOCs (Lelieveld and Dentener 2000). Among the major air pollutants, PM, nitrogen dioxide $\left(\mathrm{NO}_{2}\right)$ and ground-level $\mathrm{O}_{3}$ are still the most serious pollutants in terms of impacts on the health of European population (European Environment Agency 2018), and should be priorities in urban context.

Air pollution mitigation is a relevant EES provided by urban forests due to air pollution deposition and filtering (Nowak et al. 2006; Escobedo et al. 2011). Urban forests have been argued to phytoremediate the air by removing PM and gases (Nowak 2006; Grote et al. 2016; Sicard et al. 2018). Areas with high urban forest density, in fact, have 


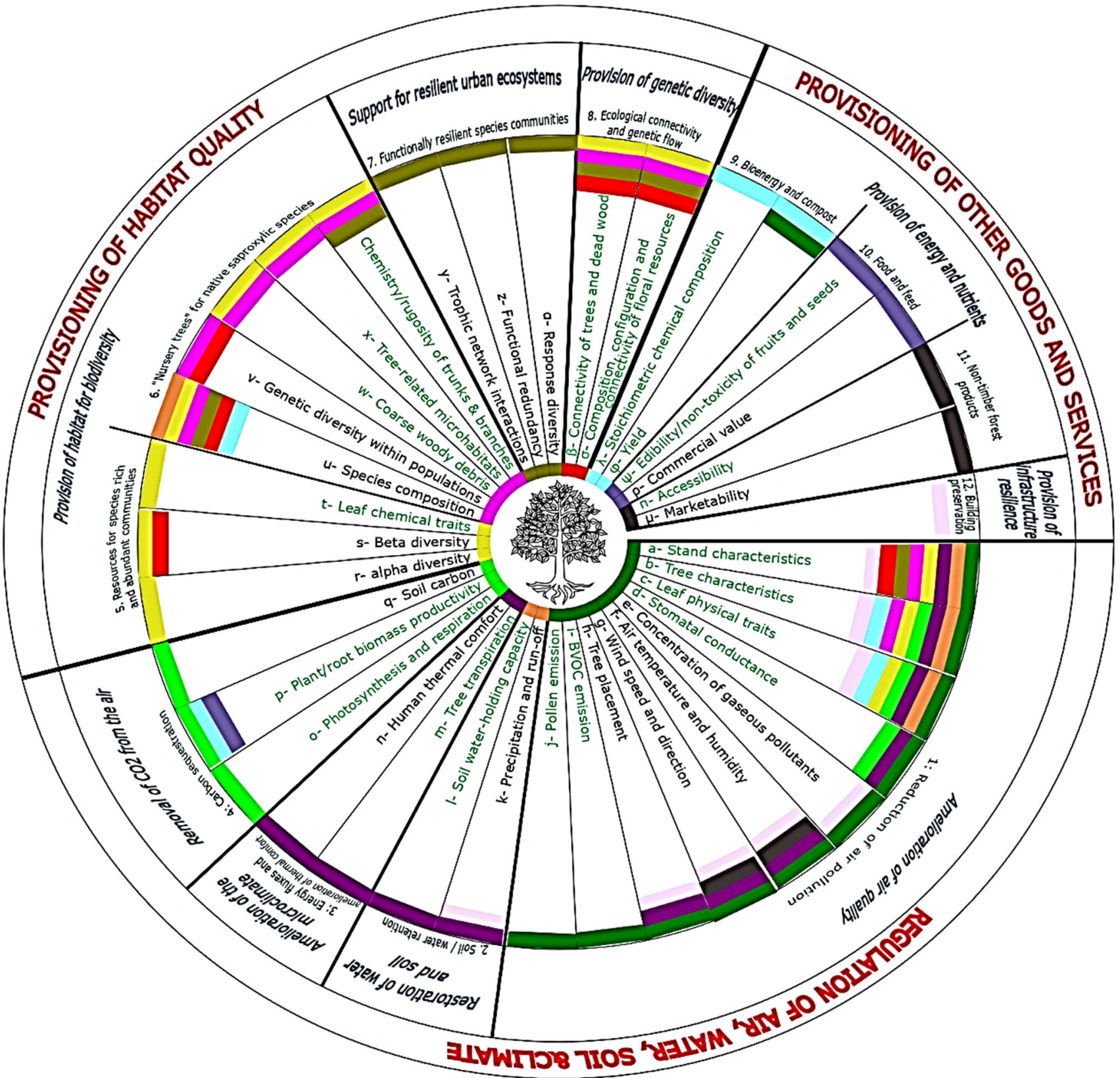

lower PM than other sites (Irga et al. 2015). Although most of the estimates suggest quite low mitigation potentials in terms of atmospheric concentrations, such small percentages translate into significant savings in terms of human health (Nowak et al. 2015, 2018).

Urban forests can reduce the concentration of pollutants in the atmosphere by direct deposition on plant surfaces and stomatal uptake of gases inside the leaves (Cieslik et al. 2009; Niinemets et al. 2014). Non-stomatal removal processes include physical deposition on any external surface, and apply to both gas and particle phases, although it is important to consider that gas exchange always occurs in a bidirectional manner (Niinemets et al. 2014). Larger tree crowns have a greater potential of ameliorating air quality by maximizing pollutant deposition (Paoletti et al. 2004), even though edges of shrubs and smaller trees can be planted extremely near the source of pollution (i.e. road traffic) and thus also maximize pollutant filtering (Popek et al. 2013; Mori et al. 2015). Therefore, the characteristics of the tree cover, in particular density and continuity of crowns, size and architecture of individual tree crowns, and leaf area per unit ground surface area (LAI), are recommended as indicators for this EES. Also, leaf surface characteristics, for example, cuticular morphology, leaf 
४Fig. 2 Classification of the three main environmental ecosystem services (EESs) provided by urban forests (in red in the outer layer), their types and benefits (1-12) (next layer), and indicators (wedges). Interlinks of each indicator to a benefit are marked by the same colour. Indicators of environment or biodiversity are written in black. Indicators of trees or forest stands are written in light green. For a description of each indicator: (a) Main stand characteristics are density, continuity and age (Vilhar and Simončič 2013; Frehner et al. 2005); (b) Main tree characteristics are architecture, DBH, LAI, canopy height, tree height (Tiwary et al. 2016; Nowak et al. 2002; Colding and Barthel 2013); (c) main leaf physical traits are shape, persistence, orientation, wettability, hairiness, roughness, toughness, albedo (Llorens and Domingo 2007); (d) (Li et al. 2007); (e) (Kumar and Imam 2013); (f) Use of vapour pressure deficit recommended (Tiwary and Kumar 2014); (g) (Tiwary and Kumar 2014); (h) Main tree placement characteristics are distance to road, arrangement, orientation (Amorim et al. 2013; Salmond et al. 2013; Vos et al. 2013; Gromke and Blocken 2015); (i) (Calfapietra et al. 2013); (j) (Cariñanos et al. 2016; Ziello et al. 2012); (k) (Gallo et al. 2012; Le Pape et al. 2012; Tiwary and Kumar 2014); (1) (Klein et al. 2014); (m) (Pataki et al. 2011); (n) (Pearlmutter et al. 2007; ShashuaBar et al. 2011); (o) (Fu et al. 2015); (p) or plant carbon storage (BISYPLAN 2012); (q) (Bae and Ryu 2015); (r) including number of species and alpha diversity (Handley et al. 2015; Ikin et al. 2015; Oishi and Tabata 2015); (s) (Knop 2016); (t) Main leaf chemical traits are chemistry and palatability (Backhaus et al. 2014); (u) Main species composition characteristics are species identity and relative abundance (Karp et al. 2011; Ikin et al. 2015; Oishi and Tabata 2015); (v) (Sadanandan and Rheindt 2015); (w) Main coarse woody debris characteristics are CWD, i.e., density of dead wood and decay stages (Lehvavirta and Rita 2002; Le Roux et al. 2014); (x) Main tree-related microhabitats characteristics are densities of cavities, cracks, bark loss, and dead branches (Lehvavirta and Rita 2002; Terho and Hallaksela 2008; Le Roux et al. 2014); (y) Main topologies of trophic network interactions are diversity, nestedness, and connectance (Baldock et al. 2015; Harrison and Winfree 2015); (z) Main functional redundancy characteristics are number of functionally redundant species within an effect group (Elmqvist et al. 2003; Laliberté et al. 2010); ( $\alpha$ ) (Elmqvist et al. 2003; Laliberté et al. 2010); (B) (Turrini and Knop 2015); ( $\sigma$ ) (Braaker et al. 2014a; Baldock et al. 2015; Harrison and Winfree 2015); ( $\lambda$ ) (AIEL 2008); ( $\varphi$ ) (Lambin and Meyfroidt 2011); $(\psi)$ (Bhat et al. 2010); ( $\rho$ ) (Lambin and Meyfroidt 2011); $(\pi)$ (McLain et al. 2012); ( $\mu$ ) (Ticktin and Shackleton 2011)

wettability and hairiness, affect PM (Kardel et al. 2012) and $\mathrm{O}_{3}$ deposition ( $\mathrm{Li}$ et al. 2018) thus representing a suitable indicator.

Another important leaf trait affecting the EES air quality is the persistence of foliage throughout the year (evergreen species) or only during the growing season (deciduous species). Stagnant atmospheric conditions combined with higher primary PM emissions from residential combustion often lead to high PM events during winter (e.g., European Environment Agency 2018). Therefore, and without considering other eventual effects, evergreen species are recommended for maximizing the PM deposition in winter. In contrast, gaseous pollutants, and in particular $\mathrm{O}_{3}$, increase during the growing season (Paoletti 2006, 2009); thus, deciduous species are better suited for filtering gaseous air

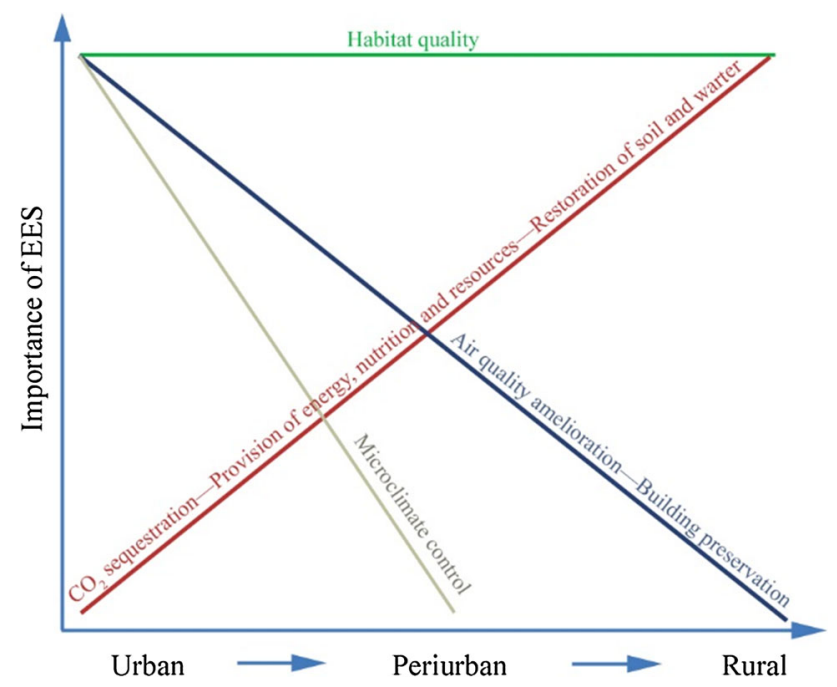

Fig. 3 Schematic representation of the main types of environmental ecosystem services (EESs) and how their relative importance changes in a rural to urban transect. The EESs provided by urban forests are similar to those provided by forests in rural areas, while the relative importance does differ except for habitat quality, which is equally important along the urban-rural gradient

pollutants provided they do not emit BVOCs or emit them at a low rate, as BVOCs favour the $\mathrm{O}_{3}$ formation (Calfapietra et al. 2013). In addition, deciduous species may have higher stomatal conductance than evergreen species (Larcher 1995) and thus maximise the air pollutant uptake through the stomata. Direct deposition on leaf surfaces may be rather limited under dry conditions, while on wet canopies this process may represent a major sink. Leaf wetness, however, is a difficult parameter to measure and cannot be proposed as an indicator, whereas the vapor pressure deficit of the air (VPD) is a simple parameter combining air temperature and relative humidity $(\mathrm{RH})$ and can be recommended as a proxy of leaf capacity for wet deposition (or release once the leaves dry out and the volatiles are gassed out).

The capacity of trees to remove pollutants may largely differ under stress conditions (Sicard et al. 2018). Species selection for air pollution mitigation should thus consider the ability of a tree species to adapt to local conditions; for example, sclerophyllous species adapt better to warm environments (Larcher 1995). A water-saving approach by actively controlling stomatal conductance is also typical in warm climates (most commonly in evergreen needleleaved species), whereas a water-spending strategy is more typical in temperate/cold regions (in deciduous broadleaved species) (Lo Gullo and Salleo 1988; Karabourniotis et al. 2014).

Inside leaves, gaseous pollutants can be scavenged by antioxidant enzymes (Niinemets et al. 2014). Although 
such scavenging ability is species-specific, extensive individual variability, broad seasonality and numerous compounds involved in scavenging make the assessment of this parameter unsuitable as an indicator of the EES air quality. Non-stomatal removal processes also include chemical deposition resulting from gas-phase reactions between pollutants (mostly $\mathrm{O}_{3}$ and $\mathrm{NO}_{\mathrm{x}}$ ) and BVOCs emitted from the ecosystem (e.g., plants or soil) (Fares et al. 2010). The emission of BVOCs is species-specific and is light- and temperature-dependent (Grote et al. 2013; Niinemets et al. 2011). High BVOC emitters are typically broadleaf plants, such as the genus Eucalyptus, Populus and Quercus, with the highest emissions occurring during spring and summer (Benjamin and Winer 1998; Calfapietra et al., 2009). The downside is that BVOCs themselves can promote higher air pollution due to the production of secondary pollutants (Calfapietra et al. 2013). Adopting low BVOC-emitting species in urban forests is thus crucial for the EES air quality (Benjamin and Winer 1998; Ren et al. 2014). In addition to the species-specific BVOC emission factor, however, the amount of emitting leaves affects the total production of BVOCs by trees. Therefore, larger crowns constitute a negative indicator of air quality in BVOCemitting species.

A trade-off (or environmental disservice) of urban forests is pollen emission. In Europe, 113 million individuals suffer from allergic rhinitis and 68 million from allergic asthma (EFA 2011); both numbers will likely increase due to climate change (Forsberg et al. 2012). Pollen affects human health by triggering such allergic reactions (Bartra et al. 2007; Cariñanos et al. 2016). Pollen deposition on leaf surfaces, however, helps to abate pollen concentrations in the air (Dzierzanowski and Gawronski 2011; Terzaghi et al. 2013) likely by mechanisms similar to those regulating PM deposition. The urban forest pollution-pollen nexus, however, is rather complex. For instance, recent evidence suggests that air pollution can change the protein profile of allergenic pollens and this may increase the symptomatic response in sensitive people (Hinge et al. 2017). The review by Grote et al. (2016), produced within COST Action FP1204, points out to crucial knowledge gaps associated with the emission of pollen and VOCs, stressing the need of holistic investigations of these interrelated processes.

Research has shown that the presence of roadside trees in street-canyons can disrupt the upwards transport of air pollutant emissions, increasing their storage within the canyon and reducing the penetration of clean air from aloft. As a result, higher pollutant concentrations may be observed at pedestrian level within vegetated canyons (Amorim et al. 2013; Salmond et al. 2013; Vos et al. 2013; Gromke and Blocken 2015), which can also constitute a disservice of the urban forests. A recent study ranked 95 urban plant species based on the ability to maximize air quality, by removing $\mathrm{O}_{3}, \mathrm{NO}_{\mathrm{x}}$ and $\mathrm{PM}$, and minimize the associated disservices (Sicard et al. 2018). However, further investigation of the inter-relations between plant characteristics, microclimate, street configuration and pollutant emissions is still warranted.

\section{Restoration of soil and water}

Urbanization can negatively impact stream and drinking water quality by increasing the loads of nutrients, metals and organic pollutants to surface and ground water (Gallo et al. 2012; Le Pape et al. 2012). Fresh water provisioning and water purification are of topical interest in urbanized areas (Vilhar and Simončič 2013). Urbanization, causing soil sealing and a reduction of vegetated surfaces, increases flooding frequency and duration due to enhanced partitioning of rainfall into runoff (Gallo et al. 2012). Urban forests contribute to stormwater harvesting through the interception of precipitation (Llorens and Domingo 2007), thereby playing a major role in sustaining urban water balance and reducing stormwater runoff (Pataki et al. 2011). Owing to their levels of influence, canopy and leaf characteristics (including canopy structure and density; shape and orientation of the leaves) are suitable indicators for this benefit.

The influence of forest cover on soil water retention capacity depends on the medium- and long-term improvement of soil conditions (Frehner et al. 2005). Urban forests can increase this capacity especially in the case of slowly drained to very wet soils, whereas improvement in well drained soils is much less (Lee 1980). Infiltration due to urban forests depends mainly on the density and continuity of tree canopies and ground vegetation cover, and is of little importance for individual street-trees (Vilhar and Simončič 2013). Soil water retention capacity is closely linked to the root system performance of trees and includes the water-holding capacity of organic and mineral soil, as well as of the litter layer (Klein et al. 2014). In cities, however, litter is often removed, e.g., to reduce the spread of plant diseases. Therefore, the indicators for this benefit are: leaf traits (shape and orientation; evergreen vs. deciduous), species composition, tree and plant cover characteristics (root system, density, continuity, and placement), precipitation and runoff, and soil water-holding capacity.

\section{Amelioration of the microclimate}

A well-known effect of urban development is the warmer temperature in cities compared to the surrounding rural 
areas, known as the urban heat island (UHI) (Oke 1982). The magnitude of warming that characterizes a given city UHI, with impacts on e.g. human comfort and energy demand, is highly variable over time and space. On average, urban temperatures are about $1-3{ }^{\circ} \mathrm{C}$ warmer than the surrounding rural environments, but under warm summer conditions they can be $>10^{\circ} \mathrm{C}$ warmer (Mills et al. 2010).

Vegetation contributes to the reduction of heat stress and wind speed even in the surrounding areas, with a cooling effect that can extend horizontally for up to $1000 \mathrm{~m}$ into the built-up area (Bowler et al. 2010; Klemm et al. 2015). The largest cooling impact of trees is observed on clear and hot summer days (Bowler et al. 2010). In winter, air temperature is slightly reduced by evergreen trees, with no clear impact on thermal comfort (Cohen et al. 2012). Cooling of air temperature due to urban forests is higher during the day than during the night in summer and the opposite is true in winter (at least in the dry-warm conditions of the study by Cohen et al. (2012)), whereas cooling of surface temperature is greater during the day in summer and nearly similar during the night throughout the year. Surface temperature within a greenspace may be $15-20{ }^{\circ} \mathrm{C}$ lower than that of the surrounding urban area, giving rise to urban air temperatures cooler by $0.3-9.5^{\circ} \mathrm{C}$ (Saaroni et al. 2018). The review paper by Saaroni et al. (2018), also supported by COST Action FP1204, showed no apparent correlation of this park-induced cooling within the climatic region, while a tendency for larger green sites ( $>2$ ha) to induce a stronger cooling effect $\left(>4{ }^{\circ} \mathrm{C}\right)$ was observed. However, the extent and magnitude of the impacts on human comfort and building energy demand are far from being effectively quantified especially due to their sitespecific nature.

Urban forests ameliorate the microclimate essentially via evapotranspiration and shading (Dimoudi and Nikolopoulou 2013). Shading by trees reduces both short-wave (direct, diffuse and reflected) and long-wave radiation emitted from surfaces (Saaroni et al. 2018). When leaves are heated by solar radiation, the cooling process takes place by evapotranspiration. Evaporation occurs from wet plant surfaces (e.g., after rainfall), while transpiration takes place through stomata. Also, shading by trees produces a net cooling effect in the below-canopy region (Akbari et al. 2001). Plant functional traits play a major role in this sense, since crown architecture and shape, leaf clumping and orientation, and the amount of foliage (often expressed as LAI) determine the interception of solar radiation (Cescatti and Niinemets 2004; Disney 2015). Evergreen trees impact the microclimate throughout the year, whereas the effect of deciduous broadleaves is mostly restricted to the growing season. This may represent a benefit in temperate regions where the penetration of sunrays through the canopy is beneficial during the winter. In fact, extensive areas of shadow are usually not desired in outdoor urban environments at high latitude cities, which creates an additional challenge for architects and urban planners (Lindberg et al. 2014).

The most relevant environmental indicators in the amelioration of the urban microclimate are air temperature and $\mathrm{RH}$, as they contribute to the thermal comfort of people (Susca et al. 2011), and wind speed and direction. The Universal Thermal Climate Index (UTCI) and the Physiologically Equivalent Temperature (PET) are useful biometeorological indices (Matzarakis et al. 1999; Bröde et al. 2012), but were considered too complex for being included in Fig. 2 as indicators.

\section{Sequestration of carbon dioxide $\left(\mathrm{CO}_{2}\right)$}

Another important benefit of urban forests is their capacity to remove $\mathrm{CO}_{2}$ from the atmosphere. This might occur directly through photosynthesis and indirectly through energy savings triggered by microclimatic amelioration (Rosenfeld et al. 1998). In cities, the anthropogenic emission of $\mathrm{CO}_{2}$ is far above the capacity of trees to sequester and store it (Briber et al. 2013). For instance, urban forests in the USA were estimated to store $712 \mathrm{Mt} \mathrm{C}$, corresponding to a gross sequestration of $23 \mathrm{Mt} \mathrm{C}$ annually (Nowak and Crane 2002), i.e., $16 \%$ of the $\mathrm{C}$ stored in natural forests (Woodbury et al. 2007). Conversely, urban forests emit $\mathrm{CO}_{2}$ to the atmosphere via respiratory processes. However, as the removal usually exceeds the emission, forests act as a net sink of atmospheric C (Thornton et al. 2002). Photosynthesis takes place under favourable conditions for plants, while stress caused by pruning or severe drought may promote respiratory processes, which in some cases induce trees to act as a net $\mathrm{C}$ source. In general, $\mathrm{CO}_{2}$ uptake capacity per leaf area unit is species-specific, being higher in deciduous broadleaves and lower in evergreen species (Wright et al. 2004). Total uptake depends on both the photosynthetic capacity and total amount of foliage, as well as on the radiation available within tree canopies (Niinemets 2015). All these traits represent suitable indicators for this EES. Sequestration capacity varies also with the type of green space, being higher in roadside vegetation that is closer to the traffic source (Wu et al. 2010). The $\mathrm{C}$ removed from the atmosphere is then stored in above- and below-ground biomass and in soil organic matter, which are other relevant indicators of the long-term capacity of urban forests to store atmospheric C. Increasing soil organic matter, however, is negligible for individual street-trees in the short term (Vidal-Beaudet et al. 2015). 


\section{Provisioning of habitat quality}

\section{Provision of habitat for biodiversity}

Forests are among the most species-rich terrestrial ecosystems (Croci et al. 2008; Jim and Liu 2001; Kühn et al. 2004). This extended multi-dimensional green space represents a resource for urban biodiversity, including wood-dwelling organisms (Grimm et al. 2008). If well designed and managed, urban forests are expected to favour the overall green connectivity across fragmented and densely built areas enhancing the permeability of the urban matrix for forest- and wood-dwelling species and for biodiversity in general (Vergnes et al. 2012; LaPoint et al. 2015).

In the last decades, biodiversity has emerged as one of the most important environmental concerns (Hooper et al. 2005). There is a growing consensus that biodiversity determines ecosystem functions and underlying services (Isbell et al. 2011; Cardinale et al. 2012) while contributing to the overall resilience of ecosystems. Thus, urban biodiversity constitutes not only a matter of scientific interest but also an object of increasing public concern, and could be particularly sensible to climate change (Puppim de Oliveira et al. 2014). An approach based on functional diversity can provide the link between biodiversity and EESs by taking into account the common functions that species perform in ecosystems or the way species respond to an environmental constraint (Pinho et al. 2016).

The EESs that urban forests provide to habitat quality can be classified into three major types: (i) provision of habitat for biodiversity; (ii) support for resilient urban ecosystems, and (iii) provision of genetic diversity (Fig. 2). These EESs provide a number of benefits that are summarized as: (5) provision of resources for species-rich and abundant communities; (6) provision of "nursery" trees for native saproxylic species; (7) support of functionally resilient species communities, and 8) provision of ecological connectivity and genetic flow (the numbers refer to Fig. 2). The benefit indicators can be either features of individual trees and forest patches or characteristics of the environment where trees and forests are located, or taxonomic and functional metrics reflecting different components of biodiversity (Fig. 2).

Species richness and population size are important components of biodiversity, which reflect the amount and complexity of available niches (e.g., type of leaves and branch architecture) and ecosystem productivity. Complex vegetation structures are likely to increase the availability of foraging and breeding resources for a multitude of organisms, enhancing the number and diversity of species within (alpha diversity) and across (beta diversity) forest stands (McElhinny et al. 2006; Tassicker et al. 2006).
Spatial and temporal heterogeneity of urban forests can be obtained by maximizing species composition and demographic structures, thus affecting the type of leaves, branch architecture, tree-related microhabitats and coarse woody debris.

Urban forests can maintain and even increase overall richness thanks to the presence of exotic plant/animal species (Pyšek 1998; Celesti-Grapow et al. 2006; Nobis et al. 2009), whose number is higher in urban environments compared to rural areas (Czech et al. 2000; McKinney 2002, 2006; Sattler et al. 2011, but see Cadotte et al. 2017). The presence of exotic animal species, especially arthropods, in the urban environment might be underestimated due to the lack of information and reference species lists. However, it is well documented that the introduction of alien species can cause negative effects on forest ecosystems, by modifying habitats and potentially disrupt some natural interactions among species, which can alter key functions in such ecosystems (McAfee et al. 2006). On the other hand it can also provide a resource for organisms from different trophic levels, thus taking over the functional role of endemic species that got locally extinct (Finerty et al. 2016; Gray and van Heezik 2016;).

Besides favouring species that use urban forests as a source of food and shelter, urban forests provide habitat for obligate canopy- and wood-dwelling organisms, also defined as saproxylic species. These species, such as fungi, mosses, lichens (Speight 1989), are dependent upon decayed wood during part of their life cycle. "Nursery" trees for saproxylic species are related to the concept of "habitat trees" defined as dead or living, very large and old microhabitat-bearing trees (Bütler et al. 2013). The presence of woody debris and the number of tree-related habitats influence the species composition and genetic diversity of these organisms, and improve the functional connectivity between forest patches and old trees (Vandekerkhove et al. 2013). Single habitat trees or parts of urban forest stands need to be well connected with floral feeding resources in sunny open green areas distributed within a few hundred meters.

Support for resilient urban ecosystems Urban forests are usually dominated by open environments and are often designed to accomplish recreational, aesthetic and regulation functions (Nowak 2006). The characteristics of urban habitats and the similarity in urban greens suggest that the species living in cities converge toward a subset of rather homogenous species sharing a common suite of traits (Haase et al. 2014; Knapp et al. 2008). This effect is recognized as 'biotic homogenization' (McKinney 2006), and have deep implications for conservation (but see Colding 2007; Lepczyk et al. 2017 when urban green space heterogeneity is included in the models). Species living in 
urban areas tend to be more generalist than species living in rural areas or into the wild (Clavel et al. 2011). The increase of ecologically similar species can lead an increase of redundancy of the assemblages (different species with similar traits, ecological roles and functions) (Alberti and Marzluff 2004). Since many ecosystem functions ultimately rely on interactions between primary producers (plants) and other trophic levels (e.g. pollinators, soil decomposers, and herbivores), the redundancy and resilience framework (e.g., Elmqvist et al. 2003) should be extended to multi-trophic systems (Lavorel et al. 2013) and include metrics of biotic interactions (for measuring functional redundancy and response diversity) as indicators of functionally resilient urban ecosystems (e.g., Frey et al. 2018; Tresch et al. 2019).

\section{Provision of genetic diversity}

Heterogeneous and structurally complex urban forests might not be enough to maintain viable populations and promote functionally resilient species communities if trees and forest patches remain isolated or too small (Turrini and Knop 2015). Communities in small and isolated patches tend to contain fewer species and to become increasingly homogenous in taxonomic and functional composition (McKinney 2006; Knapp et al. 2008; Turrini and Knop 2015), therefore reducing the response diversity of species communities (Elmqvist et al. 2003). The spatial configuration of urban forests and, in particular, habitat connectivity, defined as the connectedness of habitat patches for a given species (Fischer and Lindenmayer 2007), play important roles in enhancing taxonomic and functional stability and resilience. They favour trophic interactions, successful reproduction, dispersal and genetic exchange, and provide refuge from predators (Taylor et al. 2006), while enhancing meta-population and meta-community dynamics (Leibold et al. 2004; Vergnes et al. 2012; LaPoint et al. 2015). This is particularly important in view of new climate change stressors. The spatial scale at which ecological connectivity varies depends on species composition (LaPoint et al. 2015). For sessile and low dispersal organisms, such as plants, soil fauna and ground dwellers, the spatial configuration of urban forests acts within tens and hundreds of meters, while it expands up to a few kilometers for flying organisms such as bees, birds and bats (Sattler et al. 2010; Braaker et al. 2014a, b). Indicators of well-connected populations of forest-dwelling species and communities need to be further investigated. Movement patterns, the genetic diversity of model species and functional resilience of communities, including topologies of multi-trophic network interactions, are promising tools (La Point et al. 2015).

\section{Provisioning of other goods and services}

\section{Provision of energy and nutrients}

Another major category of EESs provided by urban forests is the provisioning of other goods and services (GómezBaggethun and Barton 2013; Hansen and Pauleit 2014). These EESs can be classified into the following two types: (i) provision of energy and nutrients; and (ii) provision of grey infrastructure resilience (Fig. 2). These EES types provide a number of benefits: (9) bioenergy and compost; (10) food and feed; (11) non-timber forest products (NTFPs); and (12) building preservation (the numbers refer to Fig. 2). Individual indicators characterizing the provisioning of different goods and services from trees or the environment are suggested and discussed below.

Two possibilities for resource recovery are usually considered: nutrient recovery via composting the foliage and/or energy recovery via biomass productivity (in terms of calorific value). Woody vegetation is an important renewable resource for bioenergy, alleviating the growing demand for cropped biofuels (de Richter et al. 2009). Large-scale commercial plantations of trees such as poplar and willow, mainly in urban parks and peri-urban woodlands, may fulfil the current drive for energy sustainability from renewable biomass (Djomo et al. 2015; Seidel et al. 2015). For example, sustainably grown tree biomass is projected to provide up to $10 \%$ of the UK energy needs by 2050 and to significantly contribute to the reduction of GHG emissions (DECC 2012). The biomass potential is evaluated by multiplying the primary production by the residue-to-product ratio, which is a tree-specific indicator (BISYPLAN 2012). The recovery of bioenergy, mainly as heat from the combustion of managed urban forests, is obtained from its heating value on a dry basis. The heating value (expressed in wet tons) is related to its typical stoichiometric chemical composition (AIEL 2008). Therefore, suitable indicators of bioenergy provision potential include tree-specific structural characteristics, biomass yield and stoichiometric chemical composition. Important limitations are the many energy crops, such as willow and poplar, which are strong emitters of allergens and BVOCs (Olofsson et al. 2005; Owen et al. 2013), and biomass combustion that emits considerable amounts of PM (Lim et al. 2015), both of which could adversely affect air quality.

Urban forests have the potential to offer a source of nutrition to urban populations (e.g., food and feed). Community scale and individual initiatives are gaining popularity for securing sustainable food production while ensuring minimal environmental footprints (Lambin and Meyfroidt 2011). Although there is a huge potential for urban forest EESs to provide a sustainable supply of nutrition from trees (e.g. fruits, seeds, roots), there are 
limitations posed by their toxicity and edibility for human consumption driven by pollution of the urban habitats (Bhat et al. 2010). Therefore, toxicity and the commercial value of products were identified as the key indicators for this benefit. In addition, productivity is considered as a measure of the volume of supply that can be acquired to meet the demand. These indicators are applicable towards ensuring cost-competitiveness and widespread sustainability incentives in both the developed and developing worlds.

Most resource management decisions are strongly influenced by urban forest EESs entering markets. Values associated with NTFPs (e.g. litter, flowers, leaves, bark, cones, galls, resins, spring buds, fungi, honey) account for approximately $25-96 \%$ of the total economic value of forests (Palahi et al. 2008). The cost-competitiveness of these products, however, largely depends on their accessibility (McLain et al. 2012) and marketability (Ticktin and Shackleton 2011), which have been identified as key indicators for assessing this benefit, together with the climatic conditions that affect NTFP growth.

\section{Provision of grey infrastructure resilience}

Incorporating urban forests into the urban built space is gaining popularity as a cost-effective and long-term measure for mitigating climate change impacts associated with proliferating grey infrastructure (CABE 2010; Hamdouch and Depret 2010; Wang et al. 2018). The role of urban forests in developing resilience and environmental stewardship in cities (Colding and Barthel 2013) and in the preservation of buildings (including bridges, car parks and historical monuments) is an emerging EES. This is mainly attributed to the altered micro-meteorological profile and chemical withering of building materials caused by air pollution and the changing climate (Kumar and Imam 2013; Tiwary and Kumar 2014). As this is influenced by an interplay between plant morphological, biophysical and chemical traits, the suitable indicators of this EES benefit include tree canopy architecture and position relative to building infrastructures, leaf physical traits, micro-meteorology and the concentration of pollutants.

\section{Conclusions}

Ecosystem services play a crucial role in the optimization of life quality in cities. Urban forests can reduce air pollution and greenhouse gas emissions, sequester carbon, regulate air temperature, mitigate stormwater runoff, reduce noise, as well as provide recreational, social, psychological and aesthetic benefits. In this study, we provide 36 indicators that can be used for quantifying urban forest EESs, predicting climate change effects on urban forests, and developing scientifically sound strategies for optimizing the management of urban forests and maximizing their EESs. These indicators may also be combined to develop summary indices, such as the "pollution flux potential" index (Tiwary et al. 2016). Around two-thirds of them are indicators of trees and forest stands and can be obtained by measurements or literature data, while one-third are indicators of environmental or biodiversity characteristics and can only be measured in situ. All these indicators allow efficient quantitative assessments of urban forest EESs on large areas and across cities, even though they still need to be adequately and rigorously tested, especially when applied across taxa, processes and services. Such an improved understanding is needed to increase the willingness of public entities (Vuletić et al. 2010) and private companies (Glück et al. 2010) to acknowledge urban forest EESs.

Cities are constantly evolving (Stott et al. 2015). Differences in the urbanization process depend on the historical background, urban design and available green spaces in and around cities. Therefore, guidelines on the optimization of EESs and the related choice of species and planting architecture are case-specific and must rely on EES indicators. Because different EESs are strongly interconnected and sometimes show complex and contrasting interactions, the choice and design of urban forests require a local but science-based approach. A "species selector" should be developed in each continent as a tool to help policy-makers to define suitable urban forest management, including proper tree species selection, by simultaneously optimizing different EESs. An emerging approach in this regard is to consider urban forests as Nature-Based Solutions in the urban environment and include them in the city management and planning. The integration of Nature-Based Solutions is recognized as a way to achieve several environmental, social, cultural, economic, policy and planning aims (Hansen and Pauleit 2014; Madureira and Andresen 2014), and as a tool to maximize city resilience to climate change while minimizing the associated disservices (e.g., maintenance costs, infrastructure damage/degradation, allergic reactions). There is still little information available on the EESs provided by urban forests and to what extent urban forests play a key role towards the optimization of EESs. It is important to recognize that urban forest EESs confer substantial economic value to human societies and activities in urban areas (Haase et al. 2014). Accurate calculations of urban forest EES capacity, based on the recommended indicators, will provide a basis for the economic evaluations of changes and enable stakeholders to estimate the trade-offs between EESs and other services, such as agricultural food production (MEA 2005) or urbanization (Dobbs et al. 2011). 
Acknowledgements This work was carried out within COST Action FP1204 GreenInUrbs. We thank the participants of our conferences for sharing their expert knowledge in defining the urban forest EES indicators and the effects of climate change and management. The publication was financially supported by the Ministry of Education and Science of the Russian Federation (the Agreement No. 02.A03.21.0008). We acknowledge ARCHES Conseils for drafting the Fig. 2. Publication was carried out within the PRIN project EUFORICC

Open Access This article is distributed under the terms of the Creative Commons Attribution 4.0 International License (http://crea tivecommons.org/licenses/by/4.0/), which permits unrestricted use, distribution, and reproduction in any medium, provided you give appropriate credit to the original author(s) and the source, provide a link to the Creative Commons license, and indicate if changes were made.

\section{References}

AIEL, Italian Agroforestry Energy Association (2008) Wood fuels handbook. www.biomasstradecentres.eu. Accessed 03 Jan 2018

Akbari H, Pomerantz M, Taha H (2001) Cool surfaces and shade trees to reduce energy use and improve air quality in urban areas. Sol Energy 70:295-310

Alberti M, Marzluff JM (2004) Ecological resilience in urban ecosystems: linking urban patterns to human and ecological functions. Urban Ecosyst 7:241-265

Amorim JH, Rodrigues V, Tavares R, Valente J, Borrego C (2013) CFD Modelling of the aerodynamic effect of trees on urban air pollution dispersion. Sci Total Environ 461-462:541-551

Armson D, Stringer P, Ennos AR (2012) The effect of tree shade and grass on surface and globe temperatures in an urban area. Urban For Urban Green 11:245-255

Backhaus S, Wiehl D, Beierkuhnlein C, Jentsch A, Wellstein C (2014) Warming and drought do not influence the palatability of Quercus pubescens Willd. Leaves of four European provenances. Arthropod-Plant Interact 8:329-337

Bae J, Ryu Y (2015) Land use and land cover changes explain spatial and temporal variations of the soil organic carbon stocks in a constructed urban park. Landsc Urban Plan 136:57-67

Baldock KCR, Goddard MA, Hicks DM, Kunin WE, Mitschunas N, Osgathorpe LM, Potts SG, Robertson KM, Scott AV, Stone GN, Vaughan IP, Memmott J (2015) Where is the UK's pollinator biodiversity? The importance of urban areas for flower-visiting insects. Proc R Soc B Biol Sci 282(1803):20142849

Bartra J, Mullol J, del Cuvillo A, Dávila I, Ferrer M, Jáuregui I, Montoro J, Sastre J, Valero A (2007) Air pollution and allergens. J Investig Allergol Clin Immunol 17:3-8

Benjamin MT, Winer AM (1998) Estimating the ozone-forming potential of urban trees and shrubs. Atmos Environ 32:53-68

Bhat R, Rai RV, Karim AA (2010) Mycotoxins in food and feed: present status and future concerns. Compr Rev Food Sci Food Saf 9:57-81

BISYPLAN (2012) The European Bioenergy System Planners webbased handbook. http://bisyplan.bioenarea.eu. Accessed 03 Jan 2018

Bowler DE, Buyung AL, Knight TM, Pullin AS (2010) Urban greening to cool towns and cities: a systematic review of the empirical evidence. Landsc Urban Plan 97:147-155

Braaker S, Ghazoul J, Obrist MK, Moretti M (2014a) Habitat connectivity shapes urban arthropod communities: the key role of green roofs. Ecology 95:1010-1021
Braaker S, Moretti M, Boesch R, Ghazoul J, Obrist MK, Bontadina F (2014b) Assessing habitat connectivity for ground-dwelling animals in an urban environment. Ecol Appl 24:1583-1595

Briber BM, Hutyra LR, Dunn AL, Raciti SM, Munger JW (2013) Variations in atmospheric $\mathrm{CO}_{2}$ mixing ratios across a Boston, MA urban to rural gradient. Land 2:304-327

Bröde P, Fiala D, Błażejczyk K, Holmér I, Jendritzky G, Kampmann B, Tinz B, Havenith G (2012) Deriving the operational procedure for the universal thermal climate index (UTCI). Int J Biometeorol 56:481-494

Bütler R, Lachat T, Larrieu L, Paillet Y (2013) Habitat trees: key elements for forest biodiversity. In: Kraus D, Krumm F (eds) Focus-managing forest in Europe, integrative approaches as an opportunity for the conservation of forest biodiversity. European Forest Institute, Joensuu, pp 84-91

CABE (2010) Urban green nation: building the evidence base. UK Commission for Architecture and the Built Environment, London, p 56

Cadotte MW, Yasui SLE, Livingstone S, MacIvor JS (2017) Are urban systems beneficial, detrimental, or indifferent for biological invasion? Biol Invasions 19:3489-3503

Calfapietra C, Fares S, Loreto F (2009) Volatile organic compounds from Italian vegetation and their interaction with ozone. Environ Pollut 157:1478-1486

Calfapietra C, Fares S, Manes F, Morani Sgrigna G, Loreto F (2013) Role of biogenic volatile organic compounds (BVOC) emitted by urban trees on ozone concentration in cities: a review. Environ Pollut 183:71-80

Calfapietra C, Niinemets Ü, Peñuelas J (2015) Urban plant physiology: adaptation-mitigation strategies under permanent stress. Trends Plant Sci 20:72-75

Cardinale BJ, Duffy JE, Gonzalez A, Hooper DU, Perrings C, Venail P, Narwani A, Mace GM, Tilman D, Wardle DA, Kinzig AP, Daily GC, Loreau M, Grace JB, Larigauderie A, Srivastava DS, Naeem S (2012) Biodiversity loss and its impact on humanity. Nature 486:59-67

Cariñanos P, Casares-Porcel M, Díaz Valle, de la Guardia A, De la Cruz Márquez R, Díaz de la Guardia C (2016) Charting trends in the evolution of the La Alhambra forest (Granada, Spain) through analysis of pollen-emission dynamics over time. Clim Change 135:453-466

Celesti-Grapow L, Pysek P, Jarosik V, Blasi C (2006) Determinants of native and alien species richness in the urban flora of Rome. Divers Distrib 12:490-501

Cescatti A, Niinemets Ü (2004) Sunlight capture. Leaf to landscape. In: Smith WK, Vogelmann TC, Chritchley C (eds) Photosynthetic adaptation. Chloroplast to landscape. Ecological studies 178. Springer, Berlin, pp 42-85

Chen J, Zhu L, Fan P, Tian L, Lafortezza R (2016) Do green spaces affect the spatiotemporal changes of $\mathrm{PM}_{2.5}$ in Nanjing? Ecol Process 5:1-13

Cieslik S, Paoletti E, Omasa K (2009) Why and how terrestrial plants exchange gases with air: a review. Plant Biol 11:24-34

Clavel J, Julliard R, Devictor V (2011) Worldwide decline of specialist species: toward a global functional homogenization? Front Ecol Environ 9:222-228

Cohen P, Potchter O, Matzarakis A (2012) Daily and seasonal climatic conditions of green urban open spaces in the Mediterranean climate and their impact on human comfort. Build Environ 51:285-295

Colding J (2007) 'Ecological land-use complementation' for building resilience in urban ecosystems. Landsc Urban Plan 81:46-55

Colding J, Barthel S (2013) The potential of 'Urban Green Commons' in the resilience building of cities. Ecol Econ 86:156-166 
Croci S, Butet A, Georges A, Aguejdad R, Clergeau P (2008) Small urban woodlands as biodiversity conservation hotspot: a multitaxon approach. Landsc Ecol 23:1171-1186

Czech B, Krausman PR, Devers PK (2000) Economic associations among causes of species endangerment in the United States. Bioscience 50:593-601

Davidson CM, Urquhart GJ, Ajmone-Marsan F, Biasioli M, Da Costa Duarte A, Díaz-Barrientos E, Grčman H, Hossack I, Hursthouse AS, Madrid L, Rodrigues S, Zupan M (2006) Fractionation of potentially toxic elements in urban soils from five European cities by means of a harmonised sequential extraction procedure. Anal Chim Acta 565:63-72

De Groot RS, Wilson M, Boumans R (2002) A typology for the description, classification and valuation of ecosystem functions, goods and services. Ecol Econ 41:393-408

de Richter DB, Jenkins DH, Karakash JT, Knight J, McCreery LR, Nemestothy KP (2009) Wood energy in America. Science 323:1432-1433

DECC, Department of Energy and Climate Change (2012) UK Bioenergy Strategy, p 86. London

Dimoudi A, Nikolopoulou M (2013) Vegetation in the urban environment: microclimatic analysis and benefits. Energy Build 35:69-76

Disney M (2015) Remote sensing of vegetation: potentials, limitations, developments and applications. In: Hikosaka K, Anten NPR, Niinemets Ü (eds) Canopy photosynthesis: from basics to applications. Advances in photosynthesis and respiration, vol 42. Springer, Berlin, pp 283-331

Djomo SN, Ac A, Zenone T, De Groote T, Bergante S, Facciotto G, Sixto H, Ciria Ciria P, Weger J, Ceulemans R (2015) Energy performances of intensive and extensive short rotation cropping systems for woody biomass production in the EU. Renew Sustain Energy Rev 41:845-854

Dobbs C, Escobedo FJ, Zipperer WC (2011) A framework for developing urban forest ecosystem services and goods indicators. Landsc Urban Plan 99:196-206

Dzierzanowski K, Gawronski SW (2011) Use of trees for reducing particulate matter pollution in air. Chall Mod Technol 2:69-73

EFA. European Federation of Allergy and Airway Diseases Patients Association (2011) Respiratory allergies-raise awareness, relieve the burden. In: Valovirta E (ed). Brussels, Belgium, p 59

Elmqvist T, Folke C, Nystrom M, Peterson G, Bengtsson J, Walker B, Norberg J (2003) Response diversity, ecosystem change, and resilience. Front Ecol Environ 1:488-494

Escobedo FJ, Kroeger T, Wagner JE (2011) Urban forests and pollution mitigation: analyzing ecosystem services and disservices. Environ Pollut 159:2078-2087

European Environment Agency (2015) Air quality in Europe-2015 report. ISBN 978-92-9213-702-1. Report No 5/2015

European Environment Agency, 2018. Air quality in Europe - 2018 report. No 12/2018. Publications Office of the European Union. Luxembourg. 83 pp. ISBN 978-92-9213-989-6

Fares S, McKay M, Holzinger R, Goldstein AH (2010) Ozone fluxes in a Pinus ponderosa ecosystem are dominated by non-stomatal processes: evidence from long-term continuous measurements. Agric For Meteorol 150:420-431

Finerty GE, de Bello F, Bila K, Berg MP, Dias ATC, Pezzatti GB, Moretti M (2016) Exotic or not, leaf trait dissimilarity modulates the effect of dominant species on mixed litter decomposition. J Ecol 104:1400-1409

Fischer J, Lindenmayer DB (2007) Landscape modification and habitat fragmentation: a synthesis. Glob Ecol Biogeogr $16: 265-280$

Forsberg B, Bråbäck L, Keune H, Kobernus M, von Krauss MK, Yang A, Bartonova A (2012) An expert assessment on climate change and health-with a European focus on lungs and allergies. Environ Health 11:S4

Frehner M, Wasser B, Schwitter R (2005) Nachhaltigkeit und Erfolgskontrolle im Schutzwald. Wegleitung für Pflegemassnahmen in Wäldern mit Schutzfunktion. Bundesamt für Umwelt. Wald und Landschaft, Bern

Frey D, Vega K, Zellweger F, Ghazoul J, Hansen D, Moretti M (2018) Predation risk shaped by habitat and landscape complexity in urban environments. J Appl Ecol 55:2343-2353

Fu ZH, Huyan JQ, Li F, Song YS, Zhao D, Li H (2015) Impacts of different surface covers on soil respiration in urban areas. Acta Ecol Sin 33(18):5500-5508

Gallo EL, Lohse KA, Brooks PD, Mcintosh JC, Meixner T, Mclain JET (2012) Quantifying the effects of stream channels on storm water quality in a semi-arid urban environment. J Hydrol 470-471:98-110

Giannico V, Lafortezza R, John R, Sanesi G, Pesola L, Chen J (2016) Estimating stand volume and above-ground biomass of urban forests using LiDAR. Remote Sens 8:1-14

Glück P, Avdibegović M, Cabaravdić A, Nonić D, Petrović N, Posavec S, Stojanovska M (2010) The preconditions for the formation of private forest owners' interest associations in the Western Balkan Region. For Policy Econ 12:250-263

Gómez-Baggethun E, Barton DN (2013) Classifying and valuing ecosystem services for urban planning. Ecol Econ 86:235-245

Gray ER, van Heezik Y (2016) Exotic trees can sustain native birds in urban woodlands. Urban Ecosyst 19:315-329

Grimm NB, Faeth SH, Golubiewski NE, Redman CL, Wu JG, Bai XM, Briggs JM (2008) Global change and the ecology of cities. Science 319:756-760

Gromke C, Blocken B (2015) Influence of avenue-trees on air quality at the urban neighborhood scale. Part II: traffic pollutant concentrations at pedestrian level. Environ Pollut 196:176-184

Grote R, Monson RK, Niinemets Ü (2013) Leaf-level models of constitutive and stress-driven volatile organic compound emissions. In: Niinemets Ü, Monson RK (eds) Biology, controls and models of tree volatile organic compound emissions, vol 5. Tree Physiology. Springer, Berlin, pp 315-355

Grote R, Samson R, Alonso A, Amorim JU, Calfapietra C, Cariñanos P, Churkina G, Fares S, Le Thiec D, Niinemets U, Mikkelsen TN, Paoletti E, Tiwary A (2016) Functional traits of urban trees in relation to their air pollution mitigation potential: a holistic discussion. Front Ecol Environ 14:543-550

Guo Z, Xiao X, Li D (2000) An assessment of ecosystem services: water flow regulation and hydroelectric power production. Ecol Appl 10:925-936

Haase D, Larondelle N, Andersson E, Artmann M, Borgstrom S, Breuste J, Gomez-Baggethun E, Gren A, Hamstead Z, Hansen R, Kabisch N, Kremer P, Langemeyer J, Rall EL, McPhearson T, Pauleit S, Qureshi S, Schwarz N, Voigt A, Wurster D, Elmqvist $T$ (2014) A quantitative review of urban ecosystem service assessments: concepts, models, and implementation. Ambio 43:413-433

Hamdouch A, Depret MH (2010) Policy integration strategy and the development of the 'green economy': foundations and implementation patterns. J Environ Plan Manag 53:473-490

Handley K, Hough-Goldstein J, Hanks LM, Millar JG, D'Amico V (2015) Species richness and phenology of cerambycid beetles in urban forest fragments of Northern Delaware. Ann Entomol Soc Am 108:251-262

Hansen R, Pauleit S (2014) From multifunctionality to multiple ecosystem services? a conceptual framework for multifunctionality in green infrastructure planning for urban areas. Ambio 43:516-529

Harrison T, Winfree R (2015) Urban drivers of plant-pollinator interactions. Funct Ecol 29:879-888 
Hinge V, Tidke J, Das B, Bhute S, Parab P, Apte K (2017) Air pollution exacerbates effect of allergenic pollen proteins of Cassia siamea: a preliminary report. Grana 56:147-154

Hooper DU, Chapin FS, Ewel JJ, Hector A, Inchausti P, Lavorel S, Lawton JH, Lodge DM, Loreau M, Naeem S, Schmid B, Setala H, Symstad AJ, Vandermeer J, Wardle DA (2005) Effects of biodiversity on ecosystem functioning: a consensus of current knowledge. Ecol Monogr 75:3-35

Ikin K, Le Roux DS, Rayner L, Villasenor NR, Eyles K, Gibbons P, Manning AD, Lindenmayer DB (2015) Key lessons for achieving biodiversity-sensitive cities and towns. Ecol Manag Restor 16:206-214

Irga PJ, Burchett MD, Torpy FR (2015) Does urban forestry have a quantitative effect on ambient air quality in an urban environment? Atmos Environ 120:173-181

Isbell F, Calcagno V, Hector A, Connolly J, Harpole WS, Reich PB, Scherer-Lorenzen M, Schmid B, Tilman D, van Ruijven J, Weigelt A, Wilsey BJ, Zavaleta ES, Loreau M (2011) High plant diversity is needed to maintain ecosystem services. Nature 477:199-202

Jim CY, Liu HT (2001) Species diversity of three major urban forest types in Guangzhou City, China. For Ecol Manag 146:99-114

Karabourniotis G, Liakopoulos G, Nikolopoulos D, Bresta P, Stavroulaki V, Sumbele S (2014) "Carbon gain vs. water saving, growth vs. defence": two dilemmas with soluble phenolics as a joker. Plant Sci 227:21-27

Kardel F, Wuyts K, Maher BA, Samson R (2012) Intra-urban spatial variation of magnetic particles: monitoring via leaf saturation isothermal remanent magnetisation (SIRM). Atmos Environ 55:111-120

Karp A, Hanley SJ, Trybush SO, Macalpine W, Pei M, Shield I (2011) Genetic improvement of willow for bioenergy and biofuels free access. J Integr Plant Biol 53:151-165

Klein T, Rotenberg E, Cohen-Hilaleh E, Raz-Yaseef N, Tatarinov F, Preisler Y, Ogée J, Cohen S, Yakir D (2014) Quantifying transpirable soil water and its relations to tree water use dynamics in a water-limited pine forest. Ecohydrology 7:409-419

Klemm W, Heusinkveld BG, Lenzholzer S, Jacobs MH, Van Hove B (2015) Psychological and physical impact of urban green spaces on outdoor thermal comfort during summertime in The Netherlands. Build Environ 83:120-128

Knapp S, Kuhn I, Schweiger O, Klotz S (2008) Challenging urban species diversity: contrasting phylogenetic patterns across plant functional groups in Germany. Ecol Lett 11:1054-1064

Knop E (2016) Biotic homogenization of three insect groups due to urbanization. Glob Change Biol 22:228-236

Kühn I, Brandl R, Klotz S (2004) The flora of German cities is naturally species rich. Evol Ecol Res 6:749-764

Kumar P, Imam B (2013) Footprints of air pollution and changing environment on the sustainability of built infrastructure. Sci Total Environ 444:85-101

Lafortezza R, Chen J (2016) The provision of ecosystem services in response to global change: evidences and applications. Environ Res 147:576-579

Laliberté E, Wells JA, DeClerck F, Metcalfe DJ, Catterall CP, Queiroz C, Aubin I, Bonser SP, Ding Y, Fraterrigo JM, McNamara S, Morgan JW, Merlos DS, Vesk PA, Mayfield MM (2010) Land-use intensification reduces functional redundancy and response diversity in plant communities. Ecol Lett 13:76-86

Lambin EF, Meyfroidt P (2011) Global land use change, economic globalization, and the looming land scarcity. Proc Natl Acad Sci 108:3465-3472
LaPoint S, Balkenhol N, Hale J, Sadler J, van der Ree R (2015) Ecological connectivity research in urban areas. Funct Ecol 29:868-878

Larcher W (1995) Physiological plant ecology, 3rd edn. Springer, Berlin, p 506

Lavorel S, Storkey J, Bardgett RD, de Bello F, Berg MP, Le Roux X, Moretti M, Mulder C, Pakeman RJ, Diaz S, Harrington R (2013) A novel framework for linking functional diversity of plants with other trophic levels for the quantification of ecosystem services. J Veg Sci 24:942-948

Le Pape P, Ayrault S, Quantin C (2012) Trace element behavior and partition versus urbanization gradient in an urban river (Orge River, France). J Hydrol 472-473:99-110

Le Roux DS, Ikin K, Lindenmayer DB, Manning AD, Gibbons P (2014) The Future of large old trees in urban landscapes. PLoS ONE 9(6):e99403. https://doi.org/10.1371/journal.pone.0099403

Lee R (1980) Forest hydrology. Columbia University Press, New York

Lehvavirta S, Rita H (2002) Natural regeneration of trees in urban woodlands. J Veg Sci 13:57-66

Leibold MA, Holyoak M, Mouquet N, Amarasekare P, Chase JM, Hoopes MF, Holt RD, Shurin JB, Law R, Tilman D, Loreau M, Gonzalez A (2004) The metacommunity concept: a framework for multi-scale community ecology. Ecol Lett 7:601-613

Lelieveld J, Dentener FJ (2000) What controls tropospheric ozone? J Geophys Res Atmos 105:3531-3551

Lepczyk CA, Aronson MFJ, Evans KL, Goddard MA, Lerman SB, Macivor JS (2017) Biodiversity in the city: fundamental questions for understanding the ecology of urban green spaces for biodiversity conservation. Bioscience 67:799-807

Li W, Wang F, Bell S (2007) Simulating the sheltering effects of windbreaks in urban outdoor open space. J Wind Eng Ind Aerodyn 95:533-549

Li S, Tosens S, Harley PC, Jiang Y, Kanagendran A, Grosberg M, Jaamets K, Niinemets Ü (2018) Glandular trichomes as a barrier against atmospheric oxidative stress: relationships with ozone uptake, leaf damage, and emission of LOX products across a diverse set of species. Plant Cell Environ 41:1263-1277

Lim MT, Phan A, Roddy D, Harvey A (2015) Technologies for measurement and mitigation of particulate emissions from domestic combustion of biomass: a review. Renew Sustain Energy Rev 49:574-584

Lindberg F, Holmer B, Thorsson S, Rayner D (2014) Characteristics of the mean radiant temperature in high latitude cities implications for sensitive climate planning applications. Int $\mathbf{J}$ Biometeorol 58:613-627

Llausàs A, Roe M (2012) Green infrastructure planning: crossnational analysis between the North East of England (UK) and Catalonia (Spain). Eur Plan Stud 20:641-663

Llorens P, Domingo F (2007) Rainfall partitioning by vegetation under Mediterranean conditions. A review of studies in Europe. J Hidrol 335:37-54

Lo Gullo MA, Salleo S (1988) Different strategies of drought resistance in three Mediterranean sclerophyllous trees growing in the same environmental conditions. New Phytol 108:267-276

Madureira H, Andresen T (2014) Planning for multifunctional urban green infrastructures: promises and challenges. Urban Des Int 19:38-49

Maes J, Liquete C, Teller A, Erhard M, Paracchini ML, Barredo J, Grizzetti B, Cardoso A, Somma F, Petersen JE, Meiner A, Royo Gelabert E, Zal N, Kristensen P, Bastrup-Birk A, Biala K, Piroddi C, Egoh B, Degeorges P, Fiorina C, Santos-Martín F, ševičius VN, Verboven J, Pereira EM, Bengtsson J, Gocheva K, Pedroso CM, Snäll T, Estreguil C, San-Miguel-Ayanz J, PérezSoba M, Grêt-Regamey A, Lillebø A, Malak DA, Condé S, Moen J, Czúcz B, Drakou EG, Lavalle C, Zulian G (2016) An 
indicator framework for assessing ecosystem services in support of the EU biodiversity strategy to 2020. Ecosyst Serv 17:14-23

Mariani L, Parisi SG, Cola G, Lafortezza R, Colangelo G, Sanesi G (2016) Climatological analysis of the mitigating effect of vegetation on the urban heat island of Milan, Italy. Sci Total Environ 569:762-773

Matzarakis A, Mayer H, Iziomon MG (1999) Applications of a universal thermal index: physiological equivalent temperature. Int J Biometeorol 43:76-84

McAfee BJ, Nealis VG, Malouin C (2006) Invasive alien species at the urban-forest interface. Environments 34:85-88

McDonald AG, Bealey WJ, Fowler D, Dragosits U, Skiba U, Smith RI, Donovan RG, Brett HE, Hewitt CN, Nemitz E (2007) Quantifying the effect of urban tree planting on concentrations and depositions of $\mathrm{PM}_{10}$ in two UK conurbations. Atmos Environ 41:8455-8467

McElhinny C, Gibbons P, Brack C, Bauhus J (2006) Fauna-habitat relationships: a basis for identifying key stand structural attributes in temperate Australian eucalypt forests and woodlands. Conserv Biol 12:89-110

McKinney ML (2002) Urbanization, biodiversity, and conservation. Bioscience 52:883-890

McKinney ML (2006) Urbanization as a major cause of biotic homogenization. Biol Cons 127:247-260

McLain RJ, MacFarland K, Brody L, Hebert J, Hurley P, Poe M, Buttolph LP, Gabriel N, Dzuna M, Emery MR, Charnley S (2012) Gathering in the city: an annotated bibliography and review of the literature about human-plant interactions in urban ecosystems, pp 107. General Technical Reports PNW-GTR-849. Portland, OR: U.S. Department of Agriculture, Forest Service, Pacific Northwest Research Station

MEA, Millennium Ecosystem Assessment (2005) Ecosystems and human well-being. A framework for assessment. Island Press, Washington, DC, p 281

Mills G, Cleugh H, Emmanuel R, Endlicher W, Erell E, McGranahan G, Ng E, Nickson A, Rosenthal J, Steemer K (2010) Climate information for improved planning and management of mega cities (needs perspective). Procedia Environ Sci 1:228-246

Mori J, Sæbø A, Hanslin HM, Teani A, Ferrini F, Fini A, Burchi G (2015) Deposition of traffic-related air pollutants on leaves of six evergreen shrub species during a Mediterranean summer season. Urban For Urban Green 14:264-273

Niinemets Ü (2015) Within-canopy variations in functional leaf traits: structural, chemical and ecological controls and diversity of responses. In: Hikosaka K, Anten NPR, Niinemets Ü (eds) Canopy photosynthesis: from basics to applications. Advances in photosynthesis and respiration, vol 42. Springer, Berlin, pp 101-141

Niinemets Ü, Kuhn U, Harley PC, Staudt M, Arneth A, Cescatti A, Ciccioli P, Copolovici L, Geron C, Guenther AB, Kesselmeier J, Lerdau MT, Monson RK, Peñuelas J (2011) Estimations of isoprenoid emission capacity from enclosure studies: measurements, data processing, quality and standardized measurement protocols. Biogeosciences 8:2209-2246

Niinemets Ü, Fares S, Harley P, Jardine KJ (2014) Bidirectional exchange of biogenic volatiles with vegetation: emission sources, reactions, breakdown and deposition. Plant Cell Environ 37:1790-1809

Nobis MP, Jaeger JAG, Zimmermann NE (2009) Neophyte species richness at the landscape scale under urban sprawl and climate warming. Divers Distrib 15:928-939

Nowak DJ (2006) Institutionalizing urban forestry as a "biotechnology" to improve environmental quality. Urban For Urban Green 5:93-100

Nowak DJ, Crane DE (2002) Carbon storage and sequestration by urban trees in the USA. Environ Pollut 116:381-389
Nowak DJ, Stevens JC, Sisinni SM, Luley CJ (2002) Effects of urban tree management and species selection on atmospheric carbon dioxide. J Arboric 28:113-122

Nowak DJ, Crane DE, Stevens JC (2006) Air pollution removal by urban trees and shrubs in the United States. Urban For Urban Green 4:115-123

Nowak D, Jovan S, Branquinho C, Augusto S, Ribeiro MC, Kretsch CE (2015) Biodiversity, air quality and human health. In: Romanelli et al. Connecting Global Priorities - Biodiversity and Human Health: A State of Knowledge Review. World Health Organization and Secretariat of the Convention on Biological Diversity, Chapter 4, p 63-74. ISBN 9789241508537

Nowak DJ, Hirabayashi S, Doyle M, McGovern M, Pasher J (2018) Air pollution removal by urban forests in Canada and its effect on air quality and human health. Urban For Urban Green 29:40-48

Oishi Y, Tabata K (2015) The importance of large trees in shrine forests for the conservation of epiphytic bryophytes in urban areas. In: Lo Y-H, Blanco JA, Roy S (eds) Biodiversity in ecosystems-linking structure and function. IntechOpen, London, UK, ISBN 978-953-51-2028-5

Oke TR (1982) The energetic basis of the urban heat island. Q J R Meteorol Soc 108(455):1-24

Olofsson M, Ek-Olausson B, Jensen NO, Langer S, Ljungström E (2005) The flux of isoprene from a willow coppice plantation and the effect on local air quality. Atmos Environ 39:2061-2070

Owen SM, Hewitt CN, Rowland CS (2013) Scaling emissions from agroforestry plantations and urban habitats. In: Niinemets $\ddot{U}$, Monson RK (eds) Biology, controls and models of tree volatile organic compound emissions. Tree physiology. Springer, Heidelberg, pp 415-450

Palahi M, Mavsar R, Gracia C, Birot Y (2008) Mediterranean forests under focus. Int For Rev 10:676-688

Pandit R, Polyakov M, Tapsuwan S, Moran T (2013) The effect of street trees on property value in Perth, Western Australia. Landsc Urban Plan 110:134-142

Paoletti E (2006) Impact of ozone on Mediterranean forests: a review. Environ Pollut 144:463-474

Paoletti E (2009) Ozone and urban forests in Italy. Environ Pollut 157:1506-1512

Paoletti E, Karnosky DF, Percy KE (2004) Urban trees and air pollution. In: Konijnendijk CC, Schipperijn J, Hoyer KK (eds) Forestry serving urbanised societies, vol 14. IUFRO World Series, IUFRO Headquarters, Vienna, pp 129-154

Pascal M, Corso M, Chanel O, Declercq C, Badaloni C, Cesaroni G, Henschel S, Meister K, Haluza D, Martin-Olmedo P, Medina S (2013) Assessing the public health impacts of urban air pollution in 25 European cities: results of the Aphekom project. Sci Total Environ 449:390-400

Pataki DE, McCarthy HR, Litvak E, Pincetl S (2011) Transpiration of urban forests in the Los Angeles metropolitan area. Ecol Appl 21:661-677

Pearlmutter D, Berliner P, Shaviv E (2007) Urban climatology in arid regions: current research in the Negev desert. Int J Climatol 27:1875-1885

Pesola L, Cheng X, Sanesi G, Colangelo G, Elia M, Lafortezza R (2017) Linking aboveground biomass and biodiversity to stand development in urban forest areas: a case study in northern Italy. Landsc Urban Plan 157:90-97

Pinho P, Correia O, Lecoq M, Munzi S, Vasconcelos S, Gonçalves P, Rebelo R, Antunes C, Silva P, Freitas C, Lopes N, Santos-Reis M, Branquinho C (2016) Evaluating green infrastructure in urban environments using a multi-taxa and functional diversity approach. Environ Res 147:601-610

Popek R, Gawrońska H, Wrochna M, Gawroński SW, Sæbø A (2013) Particulate matter on foliage of 13 woody species: deposition on 
surfaces and phytostabilisation in waxes-a 3-year study. Int $\mathbf{J}$ Phytorem 15:245-256

Puppim de Oliveira JA, Doll CNH, Moreno-Peñaranda R, Balaban O (2014) Urban biodiversity and climate change. Global environmental change. Springer, Dordrecht, pp 461-468

Pyšek P (1998) Alien and native species in Central European urban floras: a quantitative comparison. J Biogeogr 25:155-163

Ren Y, Ge Y, Gu B, Min Y, Tani A, Chang J (2014) Role of management strategies and environmental factors in determining the emissions of biogenic volatile organic compounds from urban greenspaces. Environ Sci Technol 48:6237-6246

Rosenfeld AH, Romm JJ, Akbari H, Pomerantz M (1998) Cool communities: strategies for heat island mitigation and smog reduction. Energy Build 28:51-62

Roy S, Byrne J, Pickering C (2012) A systematic quantitative review of urban tree benefits, costs, and assessment methods across cities in different climatic zones. Urban For Urban Green 11:351-363

Saaroni H, Amorim JH, Hiemstra JA, Pearlmutter D (2018) Urban Green Infrastructure as a tool for urban heat mitigation: survey of research methodologies and findings across different climatic regions. Urban Clim 24:94-110

Sadanandan KR, Rheindt FE (2015) Genetic diversity of a tropical rainforest understory bird in an urban fragmented landscape. Condor 117:447-459

Salmond JA, Williams DE, Laing G, Kingham S, Dirks K, Longley I, Henshaw GS (2013) The influence of vegetation on the horizontal and vertical distribution of pollutants in a street canyon. Sci Total Environ 443:287-298

Sattler T, Borcard D, Arlettaz R, Bontadina F, Legendre P, Obrist MK, Moretti M (2010) Spider, bee, and bird communities in cities are shaped by environmental control and high stochasticity. Ecology 91:3343-3353

Sattler T, Obrist MK, Duelli P, Moretti M (2011) Urban arthropod communities: added value or just a blend of surrounding biodiversity? Landsc Urban Plan 103:347-361

Seidel D, Busch G, Krause B, Bade C, Fessel C, Kleinn C (2015) Quantification of biomass production potentials from trees outside forests-a case study from central Germany. BioEnergy Res 8:1344-1351

Shashua-Bar L, Pearlmutter D, Erell E (2011) The influence of trees and grass on outdoor thermal comfort in a hot-arid environment. Int J Climatol 31:1498-1506

Shwartz A, Turbé A, Simon L, Julliard R (2014) Enhancing urban biodiversity and its influence on city-dwellers: an experiment. Biol Conserv 171:82-90

Sicard P, Augustaitis A, Belyazid S, Calfapietra C, De Marco A, Fenn M, Grulke N, He S, Matyssek R, Serengil Y, Wieser G, Paoletti E (2016) Global topics and novel approaches in the study of air pollution, climate change and forest ecosystems. Environ Pollut 213:977-987

Sicard P, Agathokleous E, Araminiene V, Carrari E, Hoshika Y, De Marco A, Paoletti E (2018) Should we see urban trees as effective solutions to reduce increasing ozone levels in cities? Environ Pollut 243:163-176

Speight MCD (1989) Saproxylic invertebrates and their conservation. Council of Europe, Nature and environment series 42, pp 1-81. Strasbourg

Stott I, Soga M, Inger R, Gaston KJ (2015) Land sparing is crucial for urban ecosystem services. Front Ecol Environ 13:387-393

Susca T, Gaffin SR, Dell'Osso GR (2011) Positive effects of vegetation: urban heat island and green roofs. Environ Pollut 159:2119-2126

Tassicker A, Kutt A, Vanderduys EMS (2006) The effects of vegetation structure on the birds in a tropical savanna woodland in north-eastern Australia. Rangel J 28:139-152
Taylor PD, Fahrig L, With KA (2006) Landscape connectivity: a return to the basics. In: Crooks KR, Sanjayan M (eds) Connectivity conservation. Cambridge University Press, New York, pp 29-43

TEEB, The Economics of Ecosystems and Biodiversity (2010) The economics of ecosystems and biodiversity: ecological and economic foundations. Earthscan, London

Terho M, Hallaksela AM (2008) Decay characteristics of hazardous Tilia, Betula, and Acer trees felled by municipal urban tree managers in the Helsinki City Area. Forestry 81:151-159

Terzaghi E, Wild E, Zachello G, Cerabolini BEL, Jones KC, Di Guarda A (2013) Forest filters effects: role of leaves in capturing/releasing air particulate matter and its associated PAHs. Atmos Environ 74:378-384

Thornton PE, Law BE, Gholz HL, Clark KL, Falge E, Ellsworth DS, Goldstein AH, Monson RK, Hollinger D, Falk M, Chen J, Sparks JP (2002) Modeling and measuring the effects of disturbance history and climate on carbon and water budgets in evergreen needleleaf forests. Agric For Meteorol 113:185-222

Ticktin T, Shackleton C (2011) Harvesting non-timber forest products sustainably: opportunities and challenges. Non-timber forest products in the global context. Springer, Berlin Heidelberg, pp 149-169

Tiwary A, Kumar P (2014) Impact evaluation of green-grey infrastructure interaction on built-space integrity: an emerging perspective to urban ecosystem service. Sci Total Environ 487:350-360

Tiwary A, Williams ID, Heidrich O, Namdeo A, Bandaru V, Calfapietra C (2016) Development of multi-functional streetscape green infrastructure using a performance index approach. Environ Pollut 208:209-220

Tresch S, Frey D, Le Bayon RC, Zanetta A, Rasche F, Fliessbach A, Moretti M (2019) Litter decomposition driven by soil fauna and plant diversity in urban gardens. Sci Total Environ 658:1614-1629

Turrini T, Knop E (2015) A landscape ecology approach identifies important drivers of urban biodiversity. Glob Change Biol 21:1652-1667

United Nations (2018) World urbanization prospects: the 2018 revision. Economic and social affairs. https://population.un.org/ wup/Publications/Files/WUP2018-KeyFacts.pdf. Accessed 17 Oct 2018

Vandekerkhove K, Thomaes AB, Jonsson G (2013) Connectivity and fragmentation: island biogeography and metapopulation applied to old-growth elements. In: Kraus D, Krumm F (eds) Integrative approaches as an opportunity for the conservation of forest biodiversity. European Forest Institute, Freiburg

Vergnes A, Viol IL, Clergeau P (2012) Green corridors in urban landscapes affect the arthropod communities of domestic gardens. Biol Conserv 145:171-178

Vidal-Beaudet L, Forget-Caubel V, Grosbellet C (2015) Favour street tree root growth with high supplies of organic matter induces changes in urban soil properties. Acta Hort 1099:943-950

Vilhar U, Simončič P (2013) Identification of key indicators for drinking water protection services in the urban forests of Ljubljana. South-east Eur For 3:103-113

Vos PEJ, Maiheu B, Vankerkom J, Janssen S (2013) Improving local air quality in cities: to tree or not to tree? Environ Pollut 183:113-122

Vuletić D, Posavec S, Krajter S, Paladinić E (2010) Payments for environmental services (PES) in Croatia - public and professional perception and needs for adaptation. South-east Eur For 1:51-98

Wang WJ, Zhang B, Xiao L, Zhou W, Wang HM, He XY (2018) Decoupling forest characteristics and background conditions to 
explain urban-rural variations of multiple microclimate regulation from urban trees. Peer J 6:e5450

Woodbury PB, Smith JE, Heath LS (2007) Carbon sequestration in the U.S. forest sector from 1990 to 2010. For Ecol Manag 241:14-27

Wright IJ, Reich PB, Westoby M, Ackerly DD, Baruch Z, Bongers F, Cavender-Bares J, Chapin T, Cornelissen JHC, Diemer M, Flexas J, Garnier E, Groom PK, Gulias J, Hikosaka K, Lamont BB, Lee T, Lee W, Lusk C, Midgley JJ, Navas ML, Niinemets Ü, Oleksyn J, Osada N, Poorter H, Poot P, Prior L, Pyankov VI, Roumet C, Thomas SC, Tjoelker MG, Veneklaas E, Villar R (2004) The world-wide leaf economics spectrum. Nature 428:821-827

Wu J, Li N, Chen Z, Yu S (2010) The effect of $\mathrm{CO}_{2}$ sequestration and $\mathrm{O}_{2}$ release of urban vegetation in Shenzhen special zone.
Zhongshan Daxue Xuebao/Acta Scientiarum Natralium Universitatis Sunyatseni 49:86-92

Ziello C, Sparks TH, Estrella N, Belmonte J, Bergmann KC, Bucher E, Brighetti MA, Damialis A, Detandt M, Galán C, Gehrig R, Grewling L, Gutiérrez Bustillo AM, Hallsdóttir M, KockhansBieda MC, De Linares C, Myszkowska D, Pàldy A, Sánchez A, Smith M, Thibaudon M, Travaglini A, Uruska A, ValenciaBarrera RM, Vokou D, Wachter R, de Weger LA, Menzel A (2012) Changes to airborne pollen counts across Europe. PLOS One 7:1-8

Publisher's Note Springer Nature remains neutral with regard to jurisdictional claims in published maps and institutional affiliations. 